\title{
Fraud in Nonprofit Organizations: How to Mitigate it?
}

\author{
Dr. Marvin L. J. Blye ${ }^{1}$ and Dr. Desire Luamba ${ }^{2}$ \\ ${ }^{I}$ Deputy Chief Financial Officer (CFO), City of Baltimore-Department of Housing and Community Development (DHCD), \\ Baltimore, Maryland, USA \\ ${ }^{2}$ Adjunct Faculty, Trevecca Nazarene University, Nashville, TN, USA
}

*Correspondence: Dr. Marvin L. J. Blye, marvinljblye@gmail.com

\begin{abstract}
In the United States, nonprofit organizations lose at least $\$ 40$ billion every year because of fraud. Fraud negatively affects nonprofit organizations' productivity. Nonprofit managers need effective strategies to prevent fraud, increase trust among stakeholders, and ensure longevity. The purpose of this multiple case study was to explore strategies to mitigate fraud in nonprofit organizations. The conceptual framework of this study was Cressey's fraud triangle theory. Data of this study were collected through interview questions from 4 top successful managers of nonprofit organizations in Maryland. The emerging themes after data analysis were ethics and regulatory compliance, transformational leadership, and managerial skills.
\end{abstract}

KEYWORDS: Nonprofit, Fraud, Strategies, Sustainability

\section{ARTICLE INFORMATION}

Author(s): Dr. Marvin L. J. Blye and Dr. Desire Luamba

Received: 30 Aug, 2021; Accepted: 28 Sep, 2021; Published: 10 Oct, 2021 e-ISSN: 2347-4696;

Paper Id: BMN-IJBMR-2021-69;

Citation: doi.org/10.37391/IJBMR.090401

Webpage-link:

https://ijbmr.forexjournal.co.in/archive/volume-9/ijbmr-090401.html

\section{INTRODUCTION}

Fraud negatively affects any organization's longevity and success [1, 2]. Business managers or leaders need to implement planned and non-planned internal and external controls to prevent or mitigate fraud in organizations [3, 4]. As stated by Ge et al, the role of managers in nonprofit organizations should be focused on performing services to increase trust and satisfaction among shareholders to ensure organization success. Auditors, controllers, inspectors, or loss prevention officers should play a critical role to prevent or mitigate fraud. As organization managers or leaders have the critical mission to meet the organization goals, they should rely on implementing the mission of all services or individuals who can play an important role to mitigate fraud and accomplish the mission and vision of the organization [2].

In nonprofit organizations, the role of managers should also be mitigating fraud and performing high quality of services or goods to increase customers', donors', or contributors' satisfaction to promote organizational performance. Moreover, to promote organizational growth, managers need to understand the negative impacts of fraud on business performance and productivity [5]. Integrating the concepts of the fraud triangle may contribute to increase transparency and provide solutions to fraud mitigation and prevention. Furthermore, exploring and analyzing the impacts of fraud in nonprofit organizations could lead to improve relationships between all stakeholders such as nonprofit managers, government agencies leaders, and private or official contributors.

\section{BACKGROUND}

Every year, the number of fraudulent cases in nonprofit organizations increases and has become a big concern for managers, governments, and people in the local communities $[1,6]$. According to the Association of Certified Fraud Examiners (ACFE) Report of 2016, financial fraud in nonprofit organizations is estimated at $10 \%$ of all occupational fraud cases every year with an average cost per incident of $\$ 100,000$ [7]. Scheetz, et al. [8] argued that nonprofit organizations contribute $\$ 837$ billion to the economy and provide more than 11 million jobs. According to Scheetz et al., these numbers may decline because of the increasing number of fraudulent cases. For instance, the overall number of fraudulent cases in nonprofit organizations spiked more than 20 percent between 2010 and 2016 which may affect the economy. Blye [1] advised that skimming cash, purchasing schemes, and financial statement frauds, are types of fraud that nonprofit managers should detect and prevent to secure the organization's assets and ensure organization credibility. Mackey, et al. [9] added that diversion of assets in organizations often comes from thefts, investment frauds, embezzlement, and other unauthorized uses of funds which negatively affect organization development. Johnson and Russell [10] echoed that covering up fraud in nonprofit organizations is a crime that may lead to the loss of billions of dollars in future donations to support organizations' activities. Therefore, finding appropriate strategies to mitigate fraud has become crucial for nonprofit organizations credibility, success, and growth.

\section{FRAUD TRIANGLE THEORY}

The conceptual framework for this study is the Fraud Triangle Theory, which was developed by Cressey [11]. Fraud Triangle Theory is an essential approach that helps to understand why individuals commit unethical behaviors or frauds. As described by Cressey, the key tenets of the fraud triangle theory consist of opportunity, pressure, and rationalization [11]. As per Cressey [11], these three factors must exist or be present for individuals to commit a criminal act such as fraud.

Murphy and Dacin [12] further expanded Cressey’s fraud 
triangle, confirming that the characteristics of opportunity, attitude, and individual rationalization are likely predictors of fraudulent financial acts. Managers who focus on preventing the key factors that enable fraud have the chance to reduce or mitigate fraud in their organizations. Consequently, the framework from Cressey and the expanded theory from Murphy and Dacin were a reasonable foundation for understanding strategies that some nonprofit organizations' executive managers use or need to mitigate fraudulent financial activities.

\section{METHODOLOGY}

\subsection{Population and Sampling}

The sample size of the population for this qualitative multiple case study was 4 top nonprofit executive managers of the nonprofit organizations located in Maryland, who have business and managerial experience for more than 5 years, and who have successfully mitigated fraudulent behaviors in their organizations. The state of Maryland has several nonprofit organizations and selecting an appropriate and representative sample could be challenging. To find participants, we used the Google search engine and explored official reports and sources to know, locate, and select participants who met the eligibility criteria. It was challenging to select all members of the entire population because it would be costly and a waste of time. Participants were selected using the purposive sampling method. Bloomfield and Fisher [13] argued that the purposive sampling method helps to identify and select participants who could provide rich and valuable information for the study. The purposive sampling represented participants who met the eligibility criteria which included (a) be a top executive manager of nonprofit organizations with a minimum of 5 years of managerial experience, (b) have more than 5 years of business activities in Maryland, and (c) be a member of a nonprofit organization.

\subsection{Procedures}

Data were collected through face-to-face interviews with seven open-ended interview questions. The primary research question was: What strategies do nonprofit organizations executive leaders use to reduce fraudulent financial activities? The interview questions were: (a) What strategies have you used to reduce fraudulent financial activities in your organization? (b) How do you determine if your strategies used to reduce fraudulent financial activities are working? (c) What strategies were the least effective to reduce fraudulent financial activities? (d) What, if any, strategies do you use to circumvent the pressure to commit a crime in your organization? (e)What, if any, strategies do you use to circumvent the opportunity to commit a crime in your organization? (f) What, if any, strategies do you use to circumvent the rationalization to commit a crime in your organization? and (g) What other information can you add about your strategies to reduce fraudulent financial activities?

For data triangulation, we used data from interviews, companies' documents, and public records. Researchers use methodological triangulation to improve research quality, accuracy, validity, and reliability [14-16]. The interview was
30 minutes for each participant. The compliance with interview protocol, member checking in the data collection and analysis processes, and adherence to the Belmont Report Principles, helped to mitigate biases. Belmont Report Principles recommend treating participants with respect, justice, and beneficence during the research processes to mitigate biases. For the research validity and reliability, we used triangulation and member-checking.

\subsection{Data Analysis}

According to Bernard and Ryan [17] and Patton [18], the objective of data analysis in qualitative research is to explore the meaning of data and ascertain various dispositions and implementation to present the findings. Van Den Berg and Struwig [19] added that data analysis is a paramount technique for searching data patterns and describing research data. Researchers must have the responsibility to understand the context of data analysis to present and convince readers with reliable findings. Data analysis is required because it is an interactive process, where data are systematically searched and analyzed to provide an illuminating description of the phenomena under analysis. The process of data analysis is to assemble or reconstruct the data in a meaningful or comprehensible fashion, in a way that is transparent, rigorous, and thorough, while remaining true to participants' accounts [20]. During data analysis, researchers use the data triangulation method to provide additional sources for improving accuracy, credibility, validity, and reliability [21]. Data analysis is an iterative or recurring process that leads to the creativity or development of new ideas to clarify the meaning of data [22].

For data analysis, interview recordings, interview transcripts, and notes were transcribed into NVivo 12 to identify nodes, themes, and sub-themes. As suggested by Saldana [23], researchers need to focus on data quality rather than quantity because data quality in qualitative analysis leads to credible findings. Then, data were organized into categories and by interview questions to see patterns and connections between the categories. After that, data were interpreted to see where to use the themes and connections to explain the findings. The analytic processes were initial coding, adding comments and reflections, memos, looking for patterns, theme relationships, sequences, and differences. Finally, patterns were explored, and themes generalized to the fraud triangle theory.

\section{RESULTS}

The overarching research question for this research study was: What strategies do nonprofit organizations executive leaders use to reduce fraudulent financial activities? For this research, we used a qualitative method and multiple case study design to collect information from different participants who experienced the phenomenon. A multiple case study design was useful to better understand the phenomenon and get answers to who, why, when, and how questions about fraud in nonprofit organizations. Data were collected through semistructured seven open-ended questions among four top executive leaders of nonprofit organizations located in 
Maryland. For confidentiality, participants were coded as P1, $\mathrm{P} 2, \mathrm{P} 3$, and $\mathrm{P} 4$ and their companies as $\mathrm{C} 1, \mathrm{C} 2, \mathrm{C} 3$, and $\mathrm{C} 4$.

The results from NVivo 12 software indicated three major emerging themes (a) ethics and regulatory compliance, (b) transformational leadership, and (c) managerial skills. These three themes indicated the strategies needed for top managers of nonprofits to mitigate fraud in their organizations. We also used the data saturation technique to enhance trustworthiness and validity by ensuring that participants responded to all questions, and there was no new emerging idea, code, and theme during the research. Data saturation was reached after interviewing the fourth participant because there was no new information emerging to add.

Moreover, the results of NVivo 12 indicated that participants agreed that financial pressure, lack of ethics, and weakness of controls were among the primary causes of fraud. The results from data analysis indicated that the fraud triangle theory was a crucial managerial tool to promote positive behaviors and mitigate fraud in nonprofit organizations. All four participants concluded that mitigating fraudulent behaviors was critical to ensure trust among stakeholders and organization success. All participants also admitted that promoting ethical norms and policies in an organization contributed to preventing the loss of money or other assets.

Furthermore, participants admitted that the strategy to promote internal controls by using internal auditors to check cash receipts, pay stubs, and inventories were crucial to detect and prevent accounting errors or fraud. Participants added that hiring external controllers or auditors to conduct an independent analysis of their accounting records or financial statement helped them to increase the accuracy of financial records and prevent fraud. $\mathrm{P} 1$ and $\mathrm{P} 2$ presented their strategies to mitigate fraud in the workplace by using for example the background check before hiring new employees to ensure that they hire honest and loyal people. Blye [1] and Luamba [5] confirmed fraud affects an organization's reputation and advised that managers should mitigate fraud in the workplace to increase a company's reputation and customer satisfaction. All participants admitted that increasing transparency and promoting full disclosure of financial statements contributed to mitigate fraud and increase stakeholders' satisfaction. For example, P2 indicated that full disclosure of financial reports encouraged employees to give and share their feedback for any eventual issues related to fraudulent behaviors. P1 and P4 also added that presenting a detailed financial report to all stakeholders allowed them to understand how their donations influenced the organization's goals. Moreover, participants added that their experience of disclosing financial reports to all employees, allowed employees to be aware of fraud because fraudsters will see their names listed in the organization reports. From the data analysis, the authors admitted that combining the fraud triangle theory with ethics and regulatory compliance, transformational leadership, and managerial skills were the primary strategies to prevent and mitigate fraud in nonprofit organizations.

\subsection{Theme One: Ethics and Regulatory Compliance}

The first emergent theme was ethics and regulatory compliance. Ethics and policies are guidelines for employees to know and understand what is right to do according to an organization's core values and beliefs [24]. Cumming, et al. [25] argued that increasing ethical and regulatory compliance leads to business effectiveness. Based on the fraud triangle theory, Jaroslaw [26] found that the opportunity to commit fraud may come from the lack of knowledge of ethical standards and business regulations. We analyzed the data from transcribed interviews, participants' notes, organizations' documentation, and government documents of P1, P2, P3, and $\mathrm{P} 4$ and found, as showed in Table 2 below, that compliance with ethics and regulations was strategic to mitigate fraud in nonprofit organizations.

We also found that to prevent fraud and sustain organizational activities over time, nonprofit organization leaders should also implement ethical values and regulations to increase customers' satisfaction. Stakeholders who are customers, employees, and donors should be satisfied to sustain the organization's success [27, 28]. Responses for ethics and regulatory compliance came from interview questions 1 and 2, which focused on strategies to reduce fraudulent financial activities. The responses from all participants indicated that nonprofit leaders used the concept of fraud and ethics to increase incomes and sustain their organizations to survive for a long time. Participants asserted that ethics and regulatory compliance were essential to mitigate fraud and reach employees' satisfaction because it helped employees to understand their roles and obligations in reaching the organization's mission. Girgenti and Hadley [29] argued that business leaders need to comply with both institutional regulations and ethical standards to remain competitive. $\mathrm{P} 1$, $\mathrm{P} 2$, and $\mathrm{P} 3$ presented their business strategies in which they described the positive impact of regulatory compliance. For example, P1 stated that "The organization has a written procurement and whistleblower policies that have been approved by the governing board to promote ethical values." P2 echoed, "We are constantly assessing the policies and procedures in terms of likelihood and magnitude of impact, determining a response strategy, and magnitude process." P4 added, "Improving ethical practices or behaviors contribute to discouraging the conflict of interest and fraud". After analyzing interview data and financial statements, we confirmed that nonprofit managers need to implement ethical norms to sustain businesses. P3 added, "Unethical actions are unacceptable under any conditions or circumstances." The findings also showed that ethical and regulatory compliance is critical to avoid penalization, which can affect organizations' success. Participants also argued that regulatory compliance increases honesty and loyalty among stakeholders. Participants recommended that nonprofit leaders should use fraud theory and ethical standards as managerial tools to improve transparency. The emergent theme of ethics and regulatory compliance aligned with the conceptual framework of fraud triangle theory and the body of knowledge from the analysis of this study. Based on the fraud triangle theory, promoting ethics 
and regulatory compliance allowed employees to promote positive behaviors and practices, which is crucial for mitigating fraud. All participants attested that combining ethical value and regulatory compliance in their business practices with honesty and loyalty and stakeholders' satisfaction was critical to improve organizations' success and mitigate fraud in their organizations.

\subsection{Honesty and Loyalty}

Honesty and loyalty are critical attitudes that managers should use to promote or increase stakeholders' satisfaction [30]. Parmar, et al., [31] argued that honesty and loyalty are the primary factors that contribute to increasing trust and satisfaction between organization leaders and employees. P1 and P3 stated that increasing honesty and loyalty led to transparency and fraud prevention. Moreover, P2 and P4 noted that building trust between employees and employers increased confidence because employees were free to ask questions or suggest new ideas that could contribute to promoting ethical value and mitigate fraud. For example, P2 stated that "We realize that having a strong board of directors who relied on transparency to oversee activities and establish accountability was the first defense against fraud." Based on the fraud triangle theory, honesty and loyalty are critical factors for improving business practices and preventing fraud [32].

\subsection{Stakeholders' Attitudes and Behaviors}

As stated by López-Arceiz and Bellostas [33], nonprofit organization leaders should promote good governance to increase trust among stakeholders and mitigate fraud. Nonprofit leaders or managers have the mission to assess employees, donors, and government officials' attitudes and behaviors toward their organizations to ensure the credibility of the organization when collecting and managing the funds received from donors [33]. The findings from the interviews indicated that participants wanted to understand employees, donors, and government officials' attitudes about fraud in their organizations (Table 1). P2 and P4 reported that analyzing employees, customers, and donors' behaviors enabled their companies to understand the impact of fraud on the organization's success. P2 and P4 added that this strategy allowed their companies to increase financial resources, promote customer service, improve service quality, and detect fraud. P1, P2, and P4 suggested that increasing transparency among stakeholders when presenting financial reports and other business activities increased trust and motivated them to give feedback about fraudulent behaviors. Based on the fraud triangle theory, the findings were substantial to promote stakeholders' positive attitudes, customer service, and service quality for the well-being of customers and people in the local communities.

\begin{tabular}{|l|c|c|}
\hline Nodes/Themes & $\begin{array}{l}\text { Number of } \\
\text { participants }\end{array}$ & $\begin{array}{l}\text { Participant } \\
\text { engagement (\%) }\end{array}$ \\
\hline Honesty and loyalty & 4 & 100 \\
\hline $\begin{array}{l}\text { Stakeholders' attitude } \\
\text { and behavior }\end{array}$ & 3 & 75 \\
\hline
\end{tabular}

Table 1: Ethics and Regulations Compliance.

\subsection{Emerging Theme Two: Transformational Leadership Style}

The second emergent theme was a transformational leadership style. Based on the fraud triangle theory, promoting good communication, improving job satisfaction and organizational justice are critical to mitigating and preventing fraudulent behaviors. For example, P2 and P4 argued that the use of inspiration, empathy, and confidence to align followers in the vision and mission of their organization contributed to increase stakeholder's confidence and prevent fraud. The findings from the participants' interviews indicated that the transformational leadership style was essential for hiring devoted and motivated employees to sustain the organization's productivity and longevity. Managers who hire and train devoted employees have the chance to promote change in making the right decisions at the right moment and accomplishing the company's mission [34-36]. P2 and P3 noted that their leadership styles enabled their employees to understand their organization's mission and goals. For example, P3 added, "New hire orientation and human resources reviews of the organization helped employees to understand why organization leaders must mitigate fraud to increase donors' satisfaction. P1 and P2 added that using background checks in the hiring process enabled the company to recruit good and devoted employees. P3 added that hiring good employees is critical for mitigating fraudulent behaviors. P1 and P4 also argued that promoting new employee training and employee satisfaction surveys were strategic to circumvent the rationalization to commit fraud. Based on the fraud triangle theory, transformational leadership was critical for mitigating fraud by hiring and training motivated, skilled, and devoted employees, and promoting change to increase satisfaction among stakeholders.

\subsection{Hiring and Training}

Employees are among the primary sources of production and valuable assets that promote productivity. In nonprofit organizations, executive leaders or managers need to ensure a good hiring process and job training by recruiting trustful employees who will not be involved in fraudulent practices [27, 37]. Nelissen, et al. [36] argued that promoting employee training is strategic to increase knowledge, skills, and adaptation to change in an organization. Moreover, nonprofit organization leaders need to be transformational leaders to promote good hiring and training practices, monitor and assess employees' skills, identify the causes of fraud and plan the best measures to mitigate fraud in their organizations [27]. The results of data analysis indicated that participants used a transformational leadership strategy to hire and train employees to better understand business practices and the implications of fraud in the organization.

All four participants agreed that hiring and training employees led to promoting business practices and fraud prevention. Three out of four participants indicated that their strategies to work as a team to guide the change through their inspiration contributed to use for instance managerial software and the Internet to hire the best employees, plan organizational activities, and monitor organization activities in real-time. P1, 
$\mathrm{P} 3$, and $\mathrm{P} 4$ presented their training plan and budget to ensure their commitment to training activities. P2 and P4 also presented their strategy to use background and drug tests to ensure the quality and morality of new hires. Moreover, P3 added that using the strategy to hire employees locally was useful because the company may have more tools to verify the credentials of a local employee. Based on the fraud triangle theory, it becomes clear that bad employees may commit fraud. As nonprofit organizations are like volunteer services, managers should use transformational leadership to hire credible employees, align employees on the company's goals and mission, and vetted people to prevent fraud.

\subsection{Adaptation to Change}

In the current nonprofit organization's workplaces, managers need to understand and adopt change. The rapid evolution of technology and business regulations makes change irreversible to compete, increase customer service, or act efficiently in real-time [38]. Isal, et al. [39] argued that using for instance technology innovation allows managers to assess controls, inventories, any other business activities at a low cost, and prevent fraud. The findings from interviews aligned with Isal, et al.'s [39] statement and indicated that participants used adaptation to change as a strategy to reduce fraudulent behaviors (Table 2). P1, P3, and P4 noted that adopting changes in dealing with fraudulent practices had a positive impact on mitigating fraud. P1 expressed that using automated control enabled the organization to monitor all agency materials and increase fraud prevention and detection. P3 added, "Using new technology allowed to monitor actual budget vs financial performance and oversee the reserve of funds at any time."

\begin{tabular}{|l|c|c|}
\hline Nodes/Themes & $\begin{array}{l}\text { Number of } \\
\text { participants }\end{array}$ & $\begin{array}{l}\text { Participant } \\
\text { engagement (\%) }\end{array}$ \\
\hline Hiring and training & 4 & 100 \\
\hline Adaptation to change & 3 & 75 \\
\hline
\end{tabular}

Table 2: Transformational Leadership Style.

\subsection{Emergent Theme Three: Managerial Skills}

The third emerging theme was managerial skills. Managerial skills sub-themes were business skills, experiences, and understanding of business practices. According to the fraud triangle theory, managers and organization leaders should have the capability and ability to lead efficiently an organization [40]. Gordian and Evers [3] echoed that the role of effective leaders or managers is to prevent fraud and promote success. A successful leader or manager should have managerial skills to learn from failure, experience, and to make flexible changes that fit the organization's goals. Corruption and fraud have negative impacts on organization success, and managers should have efficient managerial tools such as technology innovation, internal and external controls, and periodic business evaluation to improve transparency and prevent fraud [3].

The results of data analysis indicated that participants used their knowledge, experience, and skills to monitor business activities, analyze customers' behaviors, and mitigate fraud.
The theme management skills emerged from interview questions 4, 5, and 6, in which participants explained strategies they used to circumvent pressure, opportunity, and rationalization for employees to commit fraud. The theme management skills aligned with the fraud triangle theory because managers must understand business practices before planning to improve management weaknesses or detect fraud. All four participants affirmed that the fraud triangle theory included critical elements related to management skills. For example, P1 stated, "Using audit and organizational skills contributed to correctly complete the IRS Form on time and conduct the performance appraisal of the Chief Executive Officer (CEO) director within each calendar year." P2 and P3 used their managerial skills to improve employees' payroll and track employees' attendance every day by using for instance Raiser's Edge software. P1 and P4 added that using internal and external audits regularly allowed the organization to identify financial data misalignment. P1 added, "The organization conducts an annual audit, which is completed by a certified public accountant on time under Title 2 of the Code of Federal Regulations, and the organization's auditor presents the audit findings to the governing board." Lynch [41] argued that managers or leaders should have a basic understanding of business operations and regulations to reach success. All participants suggested increasing internal and external audit practices for transparency to detect fraud. The findings were substantial with the requirement to use management skills as a strategic tool to mitigate fraud in nonprofit organizations.

\subsection{Business Skills and Experience}

Participants agreed that business knowledge, experience, and skills were among the factors that contributed to identify, prevent, and mitigate fraud (Table 3). Mlambo, et al., [42] argued that a successful leader or manager must have business skills such as competency, problem-solving capability, adaptability, self-direction, initiative spirit, critical thinking, innovative skills, and communication skills. P1 and P2 noted that their business skills and experience helped to promote financial activities and prevent fraud. P1 and P4's statements aligned with the findings of Bennett and Hatfield [43]. Bennett and Hatfield noted that nonprofit leaders, including pastors and other religious leaders, should have audit skills and experience to ensure that financial controls and fraud prevention are adequate. P1 added that his experience of dealing with auditors contributed to understanding the implications of audits findings on organization success. Moreover, P2 and P4 added that their business skills and experience of working for many years in a nonprofit organization enabled them to be aware of fraudulent practices and use their knowledge and skills to prevent fraud at all business levels of activities. As stated by Ho and Mallick [44] having and using business skills and experiences is paramount to mitigate fraud in nonprofit organizations and meet organizational goals.

\subsection{Understanding Business Practices}

Business operations or practices are operational activities that contribute to promoting organization success [45, 46]. Per Gottschalk, controlling donor funds, grants, and fundraising 
activities in receipts and expenses is an important business practice that should always be maintained in nonprofit organizations to assess risk management and prevent accounting irregularities. P1 and P4 stated that understanding business practices is critical to detect fraudulent behaviors and prevent financial losses. Moreover, because of financial constraints, P2 and P3 used business practices to regularly permutate employees at some positions to allow them to learn and understand each position and be aware of the impact of fraud. This strategy aligned with the fraud triangle theory and the analysis of McDonnell and Rutherford [47], who argued that understanding business practices is crucial to promote positive organizational behaviors and contribute to increasing stakeholders' satisfaction.

\begin{tabular}{|l|c|c|}
\hline Nodes/Themes & $\begin{array}{l}\text { Number of } \\
\text { participants }\end{array}$ & $\begin{array}{l}\text { Participant } \\
\text { engagement (\%) }\end{array}$ \\
\hline $\begin{array}{l}\text { Business skills and } \\
\text { experience }\end{array}$ & 3 & 75 \\
\hline $\begin{array}{l}\text { Understanding business } \\
\text { practices }\end{array}$ & 4 & 100 \\
\hline
\end{tabular}

Table 3: Managerial Skills.

The overall findings of this qualitative multiple case study aligned with the research analysis and the conceptual framework of the fraud triangle theory. The authors concluded that using honesty and loyalty, transformational leadership style, and managerial skills strategies was crucial and strategic for top nonprofit leaders to mitigate fraudulent behaviors in their organizations. For the authors, nonprofit managers or leaders may have different views and strategies about mitigating fraudulent behaviors; however, finding appropriate strategies is crucial to prevent fraud and ensure organization longevity. The authors recommend that nonprofit leaders or managers who are struggling to improve transparency, increase productivity, and mitigate fraud should explore the advantage of using the fraud triangle theory and the results of this study to understand the impacts of fraudulent behaviors, detect and prevent fraud, and promote their organizations' success.

\section{CONCLUSION}

Nonprofit organizations have a mission to promote social change and economic development. The high rate of fraud in nonprofit organizations affects the viability of the organization. The pressure, rationalization, and opportunity of the individual to commit fraud have increased in both profit and nonprofit organizations and affecting organization productivity. Nonprofit organization managers need strategies to reduce or mitigate fraudulent practices to promote organizational success and sustainability. The purpose of this research was to explore strategies nonprofit leaders use to mitigate fraud in their organizations. Understanding the impact of the fraud triangle theory leads to promote awareness about fraudulent practices in organizations, ensure organization success, and increase confidence among donors, employees, and government agency leaders. Although, preventing fraudulent behaviors contributes to ensuring long-term financial goals.
Fraudulent practices have become more visible in the current business context because of the pressure, rationalization, and opportunity that individuals have. Consequently, using Cressey's fraud triangle theory, the authors indicated that managers or leaders of nonprofit organizations should implement their strategies to mitigate fraud at all business levels and should involve all stakeholders in meeting organization goals and accomplishing the organization's mission. Cressey's fraud triangle theory does not only provide strategies to detect and analyze fraud, but also provide crucial strategies to avoid, prevent, and eliminate fraud to increase business performance. Nonprofit organization leaders should understand business practices and managerial tools to develop effective strategies to sustain their organization for the long term.

The authors found three major effective strategies nonprofit organization leaders used for mitigating fraudulent behaviors in their organizations. These three strategies focused on: (a) complying with ethics and regulations to promote transparency at any time at work, (b) using transformational leadership to lead efficiently followers and motivate employees to meet organization vision and mission, and (c) using managerial skills to preserve organization assets, promote organization success, increase organization's value and image, were effective strategies that contributed to preventing fraudulent practices in nonprofit organizations. Current nonprofit managers or leaders who are struggling to mitigate fraud, academic researchers, and scholars, potential entrepreneurs, and government agency leaders can use the findings of this study to learn and understand the impact of fraudulent practices on organizations. The findings may also be constructive to implement business policies or strategies to sustain organizational success and longevity. Further, the findings may contribute to promote a positive social change by supporting the success of social programs and activities for the well-being of local community members.

\section{LIMITATIONS}

Yin [48] argued that limitations are matters that arise in a study beyond the researcher's control and can affect the results or conclusions of the study. Holloway and Galvin [49] also stated that researchers limit their studies for internal and external validity of the research. A limitation also refers to limiting conditions or restrictive weaknesses in a study [50, 51]. This study included three principal limitations. The first limitation was the number of participants who could provide a lack of perspectives of fraudulent financial activities. The second limitation was the multiple case study design selected to conduct this research. The third limitation was selecting participants who had managerial positions, responsibility, and experience to provide strategies to reduce fraudulent financial activities in nonprofit organizations. The findings of this study might not be interchangeable with other states of nonprofit organizations and might contribute to reduce fraudulent financial activities. 


\section{REFERENCES}

[1] Blye, M. L. J. (2020). Reducing the Frequency and Effects of Fraudulent Activities in Community Action Agencies (Doctoral Dissertation). Retrieved from ProQuest Dissertations and Theses database.

[2] Ge, W., Koester, A., \& McVay, S. (2017). Benefits and costs of Sarbanes-Oxley Section 404 (b) exemption: Evidence from small firms' internal control disclosures. Journal of Accounting and Economics, 63, 358-384.

[3] Gordian, M., \& Evers, J. (2017). Reducing the risk of noncompliance. Pharmaceutical Executive, 37(2), 30-31.

[4] Handoyo, B. R. M., \& Bayunitri, B. I. (2021). The influence of internal audit and internal control toward fraud prevention. International Journal of Financial, Accounting, and Management, 3(1), 45-64.

[5] Luamba, D. (2019). Strategies small business owners use to remain sustainable (Doctoral dissertation). ProQuest Dissertations and Theses database.

[6] Sahdan, M. H., Cowton, C. J., \& Drake, J. E. (2020). Forensic accounting services in English local government and the counter-fraud agenda. Public Money \& Management, 40(5), 380-389.

[7] Association of Certified Fraud Examiners (ACFE). (2016). Report to the nations on occupational fraud and abuse.

[8] Scheetz, A., Smalls, T. D., Wall, J., \& Wilson, A. B. (2020). Do employee fraud reporting intentions differ between for-profit and nonprofit organizations? Journal of Governmental \& Nonprofit Accounting, 9(1), 94-117.

[9] Mackey, T. K., Vian, T., \& Kohler, J. (2018). The sustainable development goals as a framework to combat health-sector corruption. Bulletin of the World Health Organization, 96(9), 634.

[10] Johnson, S. R., \& Russell, C. (2020). Threat finance system: A common approach to defining the problem. Special Operations Journal, 6(2), 173-195.

[11] Cressey, D. R. (1953). Other people's money: A study in the social psychology of embezzlement. New York, NY, US: Free Press.

[12] Murphy, P. R., \& Dacin, M. T. (2011). Psychological pathways to fraud: Understanding and preventing fraud in organizations. Journal of Business Ethics, 101, 601-618.

[13] Bloomfield, J., \& Fisher, M. J. (2019). Quantitative research design. Journal of the Australasian Rehabilitation Nurses Association, 22(2), 27-30.

[14] Ashour, M. L. (2018). Triangulation as a powerful methodological research technique in technology-based services. Business \& Management Studies: An International Journal, 6(1), 193-208.

[15] Osuagwu, L. (2020). Research methods: Issues and research direction. Business and Management Research, 9(3), 46-55.

[16] Santos, K. D. S., Ribeiro, M. C., Queiroga, D. E. U. D., Silva, I. A. P. D., \& Ferreira, S. M. S. (2020). The use of multiple triangulations as a validation strategy in a qualitative study. Ciencia \& saude coletiva, 25, 655-664.

[17] Bernard, H. R., \& Ryan, G. W. (2016). Analyzing qualitative data (2nd ed.). Thousand Oaks, CA: Sage Publications, Inc.
[18] Patton, M. Q. (2015). Qualitative research \& evaluation methods: Integrating theory and practice (4th ed.). Thousand Oaks, CA: Sage.

[19] Van Den-Berg, A., \& Struwig, M. (2017). Guidelines for researchers using an adapted consensual qualitative research approach in management research. Electronic Journal of Business Research Methods, 15, 109-119.

[20] Joslin, R., \& Müller, R. (2016). Identifying interesting project phenomena using philosophical and methodological triangulation. International Journal of Project Management, 34, 1043-1056

[21] Rose, J., \& Johnson, C. W. (2020). Contextualizing reliability and validity in qualitative research: toward more rigorous and trustworthy qualitative social science in leisure research. Journal of Leisure Research, 51(4), 432-451.

[22] Neale, J. (2021). Iterative categorisation (IC) (part 2): interpreting qualitative data. Addiction, 116(3), 668-676.

[23] Saldana, J. (2016). The coding manual for qualitative researchers (3rd ed.). Thousand Oaks, CA: Sage Publications, Inc.

[24] Downe, J., Cowell, R., \& Morgan, K. (2016). What determines ethical behavior in public organizations: Is it rules or leadership? Public Administration Review, 76, 898-909.

[25] Cumming, D., Hou, W., \& Lee, E. (2016). Business ethics and finance in greater China: Synthesis and future directions in sustainability, CSR, and fraud. Journal of Business Ethics, 138(4), 601-626.

[26] Jaroslaw, R. (2016). Entrepreneurial behavior in periods of deterioration of small firms' condition. Entrepreneurial Business and Economics Review, 4, 139-156.

[27] Madura, J. (2015). International financial management (12th ed.). Stamford, CT: Cengage Learning.

[28] Siebold, N. (2021). Reference points for business model innovation in social purpose organizations: A stakeholder perspective. Journal of Business Research, 125, 710-719.

[29] Girgenti, R. H., \& Hedley, T. P. (Eds.). (2016). The new era of regulatory enforcement. New York, NY: McGraw-Hill.

[30] Ferrell, O. C., Harrison, D. E., Ferrell, L., \& Hair, J. F. (2019). Business ethics, corporate social responsibility, and brand attitudes: An exploratory study. Journal of Business Research, 95, 491-501.

[31] Parmar, B. L., Keevil, A., \& Wicks, A. C. (2019). People and profits: The impact of corporate objectives on employees' need satisfaction at work. Journal of Business Ethics, 154(1), 13-33.

[32] Hui, L., Chih-Wen, W., \& Yi-Han, C. (2015). The empirical study of consumers' loyalty for display technology. Journal of Business Research, 68, 2260-2265.

[33] López-Arceiz, F. J., \& Bellostas, A. J. (2020). Nonprofit governance and outside corruption: The role of accountability, stakeholder participation, and management systems. Nonprofit Management and Leadership, 31(2), 311-333.

[34] Breevaart, K., \& Bakker, A. B. (2018). Daily job demands and employee work engagement: The role of daily transformational leadership behavior. Journal of Occupational Health Psychology, $23,338-349$.

[35] Frieder, R. E., Wang, G., \& Oh, I.-S. (2018). Linking jobrelevant personality traits, transformational leadership, and job performance via perceived meaningfulness at work: A 
moderated mediation model. Journal of Applied Psychology, $103,324-333$.

[36] Nelissen, J., Forrier, A., \& Verbruggen, M. (2017). Employee development and voluntary turnover: Testing the employability paradox. Human Resource Management Journal, 27, 152-168.

[37] Bilan, Y., Mishchuk, H., Roshchyk, I., \& Joshi, O. (2020). Hiring and retaining skilled employees in SMEs: problems in human resource practices and links with organizational success. Business: Theory and Practice, 21(2), 780-791.

[38] Garba, A. S. (2017). Promoting entrepreneurship amidst poverty and unemployment: The role of Nigerian educational policies. International Journal of Asian Social Science, 7, 684-695.

[39] Isal, Y., Pikarti, G., Hidayanto, A., \& Putra, E. (2016). Analysis of IT infrastructure flexibility impacts on IT-business strategic alignment. Journal of Industrial Engineering and Management, 9, 657-683.

[40] Munifah, S., \& Suryandari, D. (2019). The influences of the board of commissioners, board of directors, audit committee, managerial ownership, and company size to WDP opinion. Accounting Analysis Journal, 8(1), 45-51.

[41] Lynch, R. (2019). Towards an innovation link between dynamic capabilities and sustainability strategy: Options for emerging market companies. International Journal of Innovation and Technology Management, 16(04), 1940003.

[42] Mlambo, D. N., Mubecua, M. A., Mpanza, S. E., \& Mlambo, V. H. (2019). Corruption and its implications for development and good governance: A perspective from post-colonial Africa. Journal of Economics and Behavioral Studies, 11(1), 39-47.

[43] Bennett, G. B., \& Hatfield, R. C. (2018). Staff auditors' proclivity for computer-mediated communication with clients and its effect on skeptical behavior. Accounting, Organizations and Society, 68(1), 42-57.
[44] Ho, S. J., \& Mallick, S. K. (2017). Does institutional linkage of bank-MFI foster inclusive financial development even in the presence of MF I frauds? Scottish Journal of Political Economy, 64, 283-309.

[45] Gottschalk, P. (2016). Fraud examiners in financial crime investigations: The case of Save the Children in Bangladesh. Pakistan Journal of Criminology, 8 (2), 1 -12.

[46] Quesado, P. R., Aibar Guzmán, B., \& Lima Rodrigues, L. (2018). Advantages and contributions in the balanced scorecard implementation. Intangible capital, 14(1), 186-201.

[47] McDonnell, D., \& Rutherford, A. C. (2018). The determinants of charity misconduct. Nonprofit and Voluntary Sector Quarterly, 47, 107-125.

[48] Yin, R. K. (2019). Case study research and applications: Design and methods (6th ed.). SAGE Publications.

[49] Holloway, I. \& Gaivin, K. (2016). Qualitative research in nursing and healthcare 4th. John Willey \& Sons.

[50] Hanckel, B., Petticrew, M., Thomas, J., \& Green, J. (2021). The use of Qualitative Comparative Analysis (QCA) to address causality in complex systems: a systematic review of research on public health interventions. BMC public health, 21(1), 1-22.

[51] Locke, J., Beidas, R.S., Marcus, S. et al. (2016). A mixed methods study of individual and organizational factors that affect implementation of interventions for children with autism in public schools. Implementation, 1(11), 135-146.

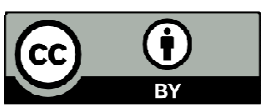

(C) 2021 by the Dr. Marvin L. J. Blye and Dr. Desire Luamba. Submitted for possible open access publication under the terms and conditions of the Creative Commons Attribution (CC BY) license (http://creativecommons.org/licenses/by/4.0/). 